\title{
GOLD NANOPARTICLES FROM MAGNETITE FOR THE DETECTION OF AMYLOID PROTEINS IN NEURODEGENERATIVE DISEASES
}

\author{
Alejandro ORTIZ, Zeyris HERRERA, Johanna MOSCOSO \\ University College of Cundinamarca, Bogotá D.C., Colombia \\ Corresponding author: Bryan Alejandro Ortiz Naranjo, e-mail: baortiz@unicolmayor.edu.co
}

DOI: 10.38045/ohrm.2022.1.02

CZU: 616.894-053.8-07:620.3

Keywords: nanoparticles, gold, magnetite, amyloid proteins, neurodegenerative diseases.
Cuvinte cheie: nanoparticule, aur, magnetită, proteine amiloide, boli neurodegenerative.
Introduction. Currently, neurodegenerative diseases (ND) are the fourth leading cause of death worldwide that pose a great challenge in the development of tools for early diagnosis. Thus, advances in science seek sensitive and selective detection systems and this manuscript will highlight the importance of nanotechnology.

Material and methods. A literature review was conducted on the representative findings of NPs technologies in neurodegenerative diseases. Articles written in both English and Spanish were included. References between 2015-2021 were also taken into account.

Results. One of the most representative techniques, AuNP was specifically implemented, together with a magnetic center composed of magnetite, which has as a specific ligand with a C-terminal cysteine domain present in the B-amyloid protein, which adhere directly to the surface of the NPs, characterizing the anomalous protein. Subsequently, by means of nanosensors capable of detecting and measuring different concentrations, these pathologies are identified at an early stage.

Conclusions. Today, along with the advent of biotechnology, it has been possible to design techniques with NPs that allow the identification of specific mutations and provide diagnosis in individuals. In the investigative models of AuNP, it is possible to infer that the capabilities that make them representative focus on their magnetism and biofunctionality, by specifically binding to amyloid peptides and other ligands present in the protein, which are the major components of amyloid plaques used in these studies.

\section{NANOPARTICULE DE AUR DIN MAGNETIT PENTRU DETECTIA PROTEINELOR AMILOIDE ÎN BOLILE NEURODEGENERATIVE}

Introducere. În prezent, bolile neurodegenerative (BN) constituie a patra cauză de deces la nivel mondial, reprezintând o mare provocare în dezvoltarea instrumentelor de diagnosticare precoce. In acest sens, se fac cercetări științifice care au în vizor sisteme de detecție sensibile și selective, de aceea în acest rezumat va fi relevată importanța nanotehnologiilor. Material și metode. A fost efectuată o cercetare a literaturii de specialitate cu privire la constatările reprezentative ale tehnologiilor nanoparticulelor (NPS) în bolile neurodegenerative. Au fost incluse articole scrise atât în engleză, cât și în spaniolă. Au fost luate în considerare și referințe apărute în 2015-2021.

Rezultate. Intr-una dintre cele mai reprezentative tehnici, au fost implementate în mod specific NPAu (nanoparticule de aur), împreună cu un centru magnetic compus din magnetit, care are ca ligand specific un domeniu cisteinic $C$-terminal, prezent în proteina $B$ amiloid, acestea aderând direct la suprafața nanoparticulelor, care caracterizează proteina anormală. Ulterior, prin intermediul nanosenzorilor, capabili să detecteze și să măsoare diferite concentrații, aceste patologii sunt identificate într-un stadiu incipient.

Concluzii. Odată cu apariția biotehnologiei, a fost posibilsă se proiecteze tehnici ce utilizează NP, care permit, la ora actuală, identificarea mutațiilor specifice și diagnosticul indivizilor. Grație modelelor de investigație cu NPAu, putem deduce că capacitățile, care le fac reprezentative, se concentrează pe magnetismul și pe biofuncționalitatea lor, prin legarea specifică de peptide amiloide și de alți liganzi prezenți în proteină, componente majore ale plăcilor de amiloid utilizate în aceste studii. 


\section{INTRODUCTION}

Currently, nanotechnology has taken a broad interest in different branches of biomedicine. In order to solve problems with potential risk to health, it is vital that different disciplines work together, thus strengthening concepts, themes and processes, which together propose assertive solutions in order to achieve optimal quality for the system called Planet Earth.

The US Environmental Protection Agency (EPA) classified particles into three general categories with respect to their size, starting with a defined range between 10,000 and 2,500 nanometers (nm) for those particles called coarse, followed by fine particles ranging between 2,500 and 100 $\mathrm{nm}$, and the last classification included the category ultrafine or nanoparticles (NPs) ranging between 100 and $1 \mathrm{~nm}$. It should be noted that these nanostructures can be generated from various materials, from metal to ceramic composites. Regarding the above mentioned, the NPs that have adopted a greater interest and detailed research in the forefront, are those that in their composition have magnetic elements formed by iron oxide, since they have biofunctional physical properties. Among its most important characteristics is its magnetic core accompanied by a polymeric shell that has the ability to bind molecules to its surface, as well as the high ratio between the surface area/size, in addition to its biocompatibility and easy biodegradation in the body (1).

The term "nano" is used to describe scientific areas and technologies that work with materials that possess at least a dimension of less than 100 $\mathrm{nm}$, that is, the construction of structures at the nanometric scale with unique properties through the manipulation of atoms and molecules, being called nanomaterials. Therefore, they can represent an optimal model as biomarkers for an early clinical diagnosis of malformed proteins or amyloid proteins present in neurodegenerative diseases (ND), since these pathologies are characterized by prolonged incubation periods, associated with a slow and irreversible fatal evolution, thus, preventing the spread of these deposits in the brain, which are the earliest key events in the progression of diseases and delaying this deterioration of poor prognosis (2).

In addition, there may occur various behavioral changes, hypersensitivity, tremors, intense itch- ing, ataxia, excitability, and seizures; vacuolization, astrogliosis and neuronal death may develop in the brain. Once the abnormal prion proteins appear, they bind and form fibers or accumulations in the central nervous system, called amyloid plaques, which may start accumulating years before the symptom onset. (3).

The prion protein, in its normal version (PrPc), after being synthesized, is modified in the Golgi apparatus and then transported to the cell surface; it is present in mammalian neuronal membranes. Recent studies have shown that it is involved in synaptic transmission, signal transduction, antioxidant activity of superoxide dismutase, neuroplasticity and cell survival. These neurodegenerative conditions can develop because a person's normal prions spontaneously change to the infectious form of the protein (PrpSc) and then alter prions in other cells in a chain reaction. The difference between the two isoforms is that PrPc has $40 \% \alpha$-helices and less than $10 \% \beta$-sheets in its tertiary structure, whereas PrpSc has about 50\% $\beta$-sheets, which makes it insoluble in non-denaturing detergents, partially resistant to proteinase $\mathrm{K}$ and highly resistant to sterilization processes, as well as to physical and chemical agents capable of degrading viral nucleic acids. The amino acid sequence of PrPc and PrpSc can be referred to as isoforms (4).

Thus, amyloidoses represent a spectrum of diseases resulting from the pathological deposition of fibrils of about 28 different protein molecules including immunoglobulin light chains, polypeptide hormones, transport molecules, transthyretin, amyloid A polypeptide, Tau protein, amyloid precursor protein, huntintin and others (5).

Therefore, for the use of these NPs as biomarkers of amyloid proteins it is of vital importance to determine that those new metals with magnetic core components to be used lack cytotoxic effects and are absolutely biocompatible; therefore, magnetite is one of the research focuses. After being metabolized, the iron ions of these particles are added to the iron deposits of the organism and eventually incorporated by the erythrocytes as part of the hemoglobin. In addition, they have a gold coating that protects the iron oxide nuclei from oxidation when present in body fluids, providing optical properties and a surface with a good capacity to be biofunctionalized (6). 
Magnetite $\left(\mathrm{Fe}_{3} \mathrm{O}_{4}\right)$ is found disseminated as an accessory mineral in many igneous rocks sometimes forming large masses of ore that are generally very titaniferous and appears associated with crystalline metamorphic rocks. In mining, gold is separated from magnetite, after the separation, synthesis methods are used to obtain gold nanostructures. In Colombia magnetite is totally wasted, important and considerable amounts of magnetite can be found at the end of the processes of the deposits, reaching even more than $40 \%$ in weight of the material treated to obtain gold. This percentage of magnetite is totally wasted after the fire assays that are carried out in an artisanal way, aggravating the environmental problem and favoring the continuity of mineral waste (7).

\section{MATERIAL AND METHODS}

A literature review was conducted on the representative findings and diagnostic potential of AuNP technologies in neurodegenerative diseases. This review was carried out from a scientific database, using ScienceDirect, PubMed, Scopus, Web of Science, during the month of March of this year.

Articles written in both English and Spanish were included, a search that yielded 50 articles, of which 20 were filtered that met the requirements of the study in progress. References between 2015-2021 were also considered as related publications of interest.

The focus of the manuscript is concurrent to the ENs that are currently the fourth leading cause of death worldwide, advances in science seek to make an early diagnosis to the development of these. One of the most representative methods consists in the design of a supercrystal capable of acting as a nanoantenna that identifies the molecule by means of a biofilm interpolated on the surface of the AuNP for the aggregation of a specific part in the peptide conformation of the protein of interest, then the supercrystal is immersed with an optical sensor in a sample of plasma or centrifuged blood. The sensor then generates an extremely high electric field on the crystal surface, quantifying its presence (8).

\section{RESULTS}

The prion theory assumes the existence of two foldings for a single amino acid sequence and the refolding of normal PrPc by the action of pathological PrpSc, suggesting a flow of information from one protein to another at the level of tertiary structure. For this reason, prions are the only living particles that contradict the central dogma of biology (9). In addition, some theories assure that PrPc has a viral origin, these affirm that the viral gene could belong to a retrovirus that infected a vertebrate from which the rest of them evolved. Therefore, the gene was incorporated into the genome forever. However, despite this, there is still no accepted study that fully shows what could be the origin of this protein (4).

It should be noted that there is currently no function of PrPc that has been specifically determined. Although some scholars mention the possibility, that PrPc protein has a possible role in copper metabolism and antioxidant defense. In addition, there is evidence that it would have enzymatic function of superoxide dismutase (SOD), as well as interaction with other proteins.

Likewise, PrPc in endothelial cells that form part of the blood-brain barrier accumulates at cellcell junctions and participates in the transmigration of monocytes from peripheral tissues to the brain possibly by specific recognition of certain molecules on the surface of monocytes (10).

In some proposed methodologies, such as cultured cells treated with neuronal growth factor (NGF), it is mentioned that PrPc favors neuritogenesis through the laminin-PrPc complex, so it is thought that it could be involved in ligand recognition and cell adhesion, by which proliferation and survival signals are triggered in cells.

PrPc is able to bind to heparins and heparin-like compounds. Heparin is a sulfated polyanion similar to glycosaminoglycans, which are part of the composition of amyloid plaques that arise in the presence of PrpSc. Heparin molecules sequester PrPc preventing it from binding to glycosaminoglycans by competition. It also binds to NCAM protein, a neuronal adhesion molecule, NF-E2-related factor 2, which is a transcription factor, Bcl-2 and apolipoprotein E, a membrane protein involved in Alzheimer's disease. In addition, this occurs in the clathrin-coated holes of the plasma membrane.

Another protein characterized as a ligand of PrPc is the $37 \mathrm{kDa}$ laminin receptor precursor. It was 
detected that there is interaction of this receptor and PrPc both in vitro and in vivo and it is also overexpressed in organs that accumulate PrpSc. It is currently believed that this is the receptor for PrpSc in mammalian cells in vivo, although it is most likely not the only one.

Through its localization in the membrane, PrPc could participate in signal transduction path- ways. According to some authors, prion infection affects the function of calcium channels.

Nanoparticles represent an appropriate tool for potential biomedical diagnostic and therapeutic applications due to their ability to be biofunctionalized and guided to a specific region of the organism by an external magnetic field (fig. 1) (1).

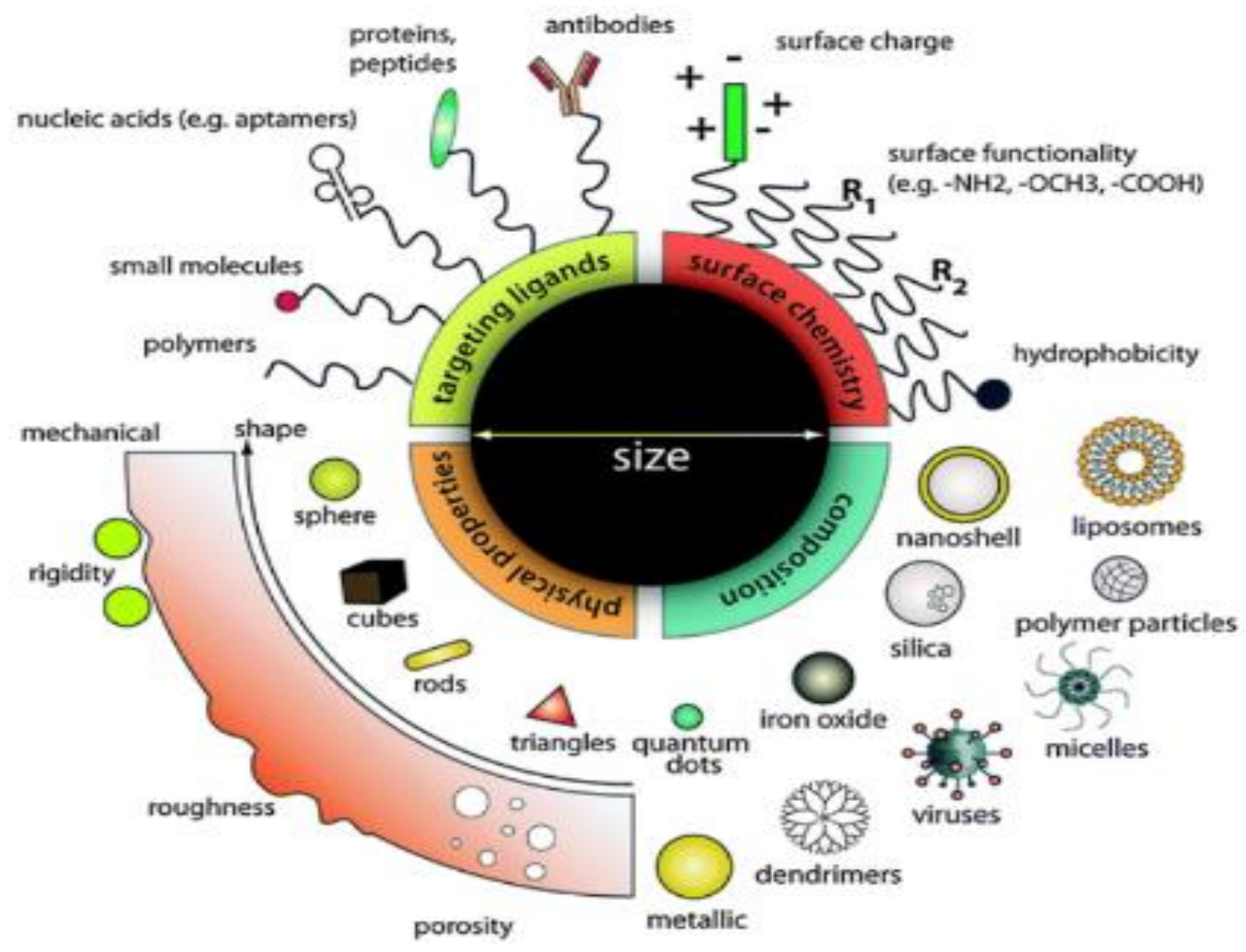

Figure 1. Nanoparticles. Characteristic aspects that make a nanoparticles a sensitive and selective material to be used as a diagnostic technique (1).

In the same way, since these nanomaterials have different usable characteristics and by means of different chemical reactions, they can be directed to different biological molecules with the final objective of being recognized, thanks to ligands expressed by molecules of interest, and thus, achieve their accumulation to be magnetically marked. Due to the limitation imposed by the low concentrations of PrpSc in certain biological samples, they are not detectable using other conventional methods, i.e., those would allow their aggregation.

The NPs are defined as a particles of matter that is between 1 and 100 nanometers in size. NPs emerged as tools for therapeutic, diagnostic and drug delivery applications. They can be synthesized from a wide range of materials, such as polymers, metals or carbon-based molecules. NPs are also highly functional due to the ease with which their shape, size and surface proper- 
ties can be modified; they can also be altered by binding other substances to the surface or trapping them within their cavities (11).

Several tools based on nanobiosensors have been designed and tested as markers for the diagnosis of ND by implementing gold, since it is a very stable metal also at the nanoscale. It is a good conductor of electrons and has a strong response when excited by an optical field (12).

The microspheres signal and detect betaamyloid in patients with NAFLD, where samples are collected from cerebrospinal fluid (CSF), serum and plasma for detection. They help to immobilize the altered protein, thus promoting efficient biomarker function (13).

Nanodiagnostics is an emerging field of research in which NPs are intentionally introduced into the human body. The enormous surface-to-mass ratio of NPs of interest is of vital importance for the study of surface effects of amyloid peptides (14). Surface effects have been proposed for amyloid protein assembly in vivo, as they may explain why amyloid proteins misfold at concentrations that are insufficient for peptide fibril formation in solution in vitro. The surfaces of the NPs provide an external constraint to the aggregation of these peptides and thus may act to catalyze the aggregation process, where the surface itself may accelerate or inhibit amyloid peptide accumulation depending on the intrinsic propensity for amyloid peptide incorporation into solution (15).
In figure 2, the expression of biomolecule binding to a surface is due to a balance between adsorption energy gain and entropy loss. Physisorption is the main mechanism driving the coating of inorganic surfaces by biomolecules in biological media. It is based on the attractive forces present between the protein or peptide to the surface. The forces leading to physisorption are electrostatic (Coulomb) interactions between opposite charges, hydrogen bond formation and Van-der-Waals interactions. Some amino acid side chains (e.g. thiols) can also be chemosorbed to surfaces leading to essentially covalent binding of the peptide. Tuning the properties of the protein by changing its sequence can lead to very high affinities towards a specific surface. Such highly optimized peptides are used, for example, to coat the surface of implants to improve their biocompatibility. Surface coatings prevent denaturation of native protein structures (16).

Therefore, magnetite is a very dense, fragile, hard mineral with ferromagnetic properties, capable of attracting iron and steel along with other metals. Any magnetic field is a consequence of a flow of electrons, its strong magnetism is due to a phenomenon of ferrimagnetism: the magnetic moments of the different iron cations of the system are strongly coupled, by anti ferromagnetic interactions, but in such a way that in each united cell there is an uncompensated magnetic moment. The sum of these uncompensated magnetic moments, strongly coupled to each other, is responsible for magnet

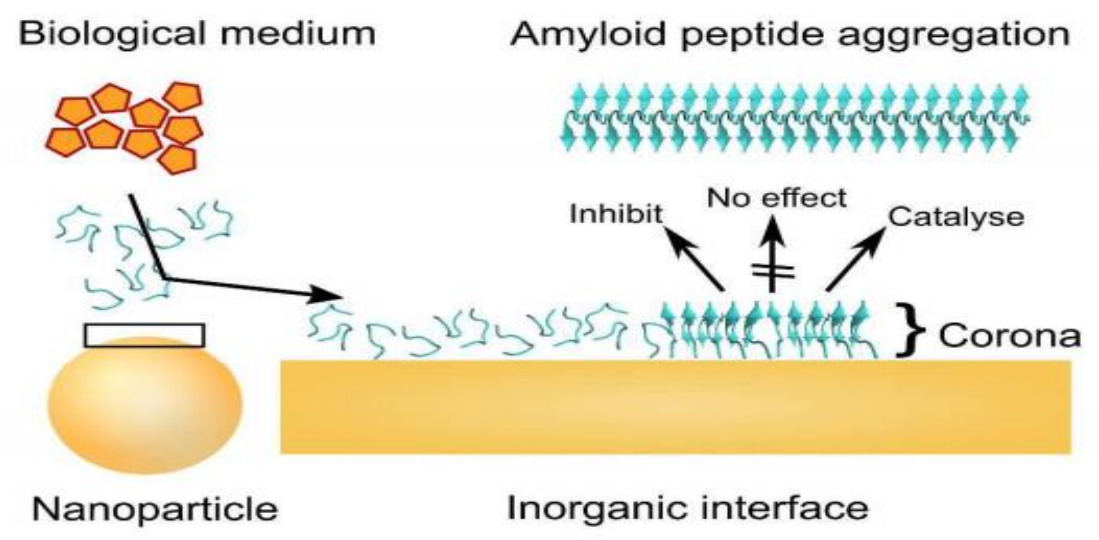

Figure 2. Schematic description: Effects of non-biological media (inorganic solid surfaces or NPs, shown in yellow) on the aggregation rate of amyloid peptides or proteins (shown in cyan). Upon contact with a biological medium, the surfaces of the inorganic NPs become coated with a biofilm, called a "corona". The surface of the NPs and the resulting corona can determine whether the aggregation of the amyloid peptide is influenced, e.g. catalysed or inhibited (16). 
ite being a magnet. In Colombia, alluvial type mining, the excavation modality is vertical, approximately $5 \mathrm{~g}$ of gold is extracted daily, as last is the separation of magnetite from gold, this is totally wasted, without counting that it contains interesting amounts of gold in NPs that can be well exploited (17).

On the other hand, the most common disorders nowadays are: Parkinson's disease, Alzheimer's disease, prion diseases and amyotrophic lateral sclerosis, which can be classified as proteinopathies, synucleinopathies, amyloidopathies and taupathies, respectively; therefore, NPAu have a potential capability as a possible diagnostic of pathological protein aggregation, this could be a promising approach in the treatment of such diseases. NPs can promote or inhibit protein aggregation, depending on coating, shape, size, surface charge and concentration. A variety of common pathogenic features have been identified, such as genetic and environmental factors, however, the most common feature of all these diseases is protein misfolding in specific regions of the brain; they are identified as the intra- or extracellular accumulation of aggregates in the central nervous system that are abundant in $\beta$ sheets (17).

Amyloidosis is known as a clinical disorder resulting from extracellular deposits of amyloid fibrils in vivo. Amyloid fibrils are highly symmetrical elongated protein aggregates that share a pattern of characteristics for their quaternary structure. These fibrillar structures, are associated with numerous diseases, including Alzheimer's disease, (A $\beta$-peptide, tau protein), spongiform encephalitis (prion proteins), type 2 diabetes (human islet amyloid polypeptide, hIAPP) and Parkinson's ( $\alpha$-synuclein). Amyloid peptides are soluble in their native state and only aggregate under specific circumstances. Whether aggregated fibrils or soluble intermediates are toxic in the development of the associated diseases is still under investigation.

One of the hypotheses that amyloid beta peptides ( $(B A)$ of Alzheimer's disease behave like prions was published in a paper using an experimental model with transgenic mice. In these the expression of the mutant forms was controlled by the promoter of the gene encoding for glial fibrillary acidic acidic protein (GFAP) and were coupled to the gene encoding for the enzyme luciferase, in order to detect and monitor in time the brain bioluminescence signals. This was confirmed by Western blot assays, enzyme-linked immunosorbent assays and immunocytochemistry, which showed a relative increase in amyloid protein, an increase in GFAP protein and a bilateral distribution of amyloid in both hemispheres of the forebrain (5).

On the other hand, there is also experimental evidence that inclusions or Lewy bodies, whose main component is $\alpha$-synuclein, are present in Parkinson's disease, and that the development of these intracellular aggregates by misfolding of $\alpha$ synuclein can spread cell to cell. These results and others have led to the hypothesis that a prion-like mechanism exists to explain the spread of $\alpha$-synuclein in the nervous system (18).

The theory of exosomes in the propagation of NEs is given by the abnormal aggregation of proteins that has been implicated in neurodegenerative processes. The transmission of these protein aggregates between neurons is the mechanism underlying the progression and pathophysiology of diseases. However, the precise mechanism by which these aggregates are transmitted between neurons is unknown. Preformed protein aggregates are the seeds of more complex protein aggregates, which occur during the lag phase of the cell cycle, a molecular principle that underlies prion infectivity and transmissibility, and thus may apply to the interneuronal transmission of protein aggregates. The mechanism dependent on preformed proteins has not been fully tested; but another possibility is that protein aggregates may be propagated by interneuronal transfer, although this mechanism is not well defined. Exosomes play important roles in the interneuronal transmission of pathogenic proteins in neurodegeneration (10).

The spectrum of clinical signs of these diseases, when fully developed, include pyramidal (spastic paresis with pyramidal tract signs) and extrapyramidal dysfunction, and akinetic mutism and unresponsiveness.

The AuNP system is based on the monitoring of protein structural changes, i.e. the biomarkers exhibit specific receptors that bind to the abnormal protein portions allowing the visualization of protein interactions with the NPs. This technique is characterized by its high sensitivity and specificity in the early determination of ENs 
in vitro. To understand the interaction between the AuNP and the abnormal amyloid aggregateforming proteins, it is necessary to know that the proteins present in the serum sample induce the formation of a corona that covers the surface of the AuNP, this biocompatibility is due to the fact that the instrument contains specific markers for such recognition.

To understand the interaction between the AuNP and the abnormal amyloid aggregate-forming proteins, it is necessary to know that the proteins present in the serum sample induce the formation of a corona that covers the surface of the AuNP, this biocompatibility is due to the fact that the instrument contains specific markers for such recognition.

The center of the sphere is composed of magnetite; ferrous-differric oxide, which has magnetic properties that are used as affinity probe with misfolded proteins, such aggregation occurs on the surface of the nanodevice which is specifically directed to the region of the C-terminal domain of the protein. The experimental model presents important properties on its surface, given the resulting force of attraction between the peptide and the surface of the AuNP, forming an amyloid aggregation effect; this also implies that a secondary ordering mechanism on the surface of the NPs is determined by the rate of formation of fibrils.

On the other hand, these assays were carried out with the exposure of the AuNP to a solution of amyloidogenic peptides with a specific concentration; the objective was to cover the NPs with these proteins. Once the contact of the proteins with the AuNP was formed, the suspension was observed. In the substrate, a higher intensity of detection was evidenced in the C-terminal domains of the anomalous protein, since the receptors of the NPs recognized the protein and acted as a marker for the detection of the structures related to the target point to be analyzed. It should be taken into account that NPs are unstable at certain $\mathrm{pH}$ values or ionic strengths of electrolytes depending on their nature (19).

\section{DISCUSSIONS}

NPs can hinder the self-assembly of peptides into amyloid fibrils by binding to specific peptide fragments and thus inhibiting their aggregation. The $\beta$-sheet tendency interacts easily with the gold surface, whereas other conformations, such as $\alpha$-helices, needed to be deflected.

Simulations suggest that AuNP binds specifically to the $\mathrm{C}$-terminal fragment region; this implies that for all peptides, initial contact through a charged group with the gold surface leads to an upward concentration and local alignment of peptide monomers on the surface. This alignment is the potential cause of the formation of a first layer of $\beta$-sheet-rich oligomers. In all cases, the $\mathrm{N}$-terminus shows greater alternation than the $\mathrm{C}$-terminus, indicating a binding of the $\mathrm{C}$ terminus to a surface, this binding on the surface occurs on a short time scale (fig. 3) (16).

To study this prototype AuNP-based biomarker and its applications to treat ENs as a diagnostic targeting amyloid fibrils, the methodology in which NPs are developed that supports an immediate binding of the amyloid peptide to the gold sensor surface, after peptide adsorption, sensors detect and quantify must be elucidated. The peptide molecules form a rigid layer on the gold surface, suggesting tight binding and structure formation on the surface (fig. 4).

Data from different sources claim that the hydrophobic C-terminal sequence of $A \beta$ folds into a $\beta$ conformation, and that $A \beta$ fibrils are composed of multiple $\beta$ units that polymerize in a parallel, in-register orientation (19).

Regarding the relationship between amyloid proteins in different neurodegenerative pathologies, it has been proposed that common neurodegenerative disorders, such as Alzheimer's disease, Parkinson's disease, Huntington's disease and their amyloidogenic proteins can selfreplicate as prions, with a neurotoxic profile in the nervous system and are considered as prionlike diseases. In fact, Tau, B-amyloid and $\alpha$ synuclein have the ability to spread cell to cell (5).

Although $\beta A$ aggregates and $\alpha$-synuclein aggregates behaved similarly to prions in experimental models, there is currently no evidence that Alzheimer's disease and Parkinson's disease are contagious, in the sense of being transmissible between humans.

In addition to this, prion diseases or spongiform encephalopathies are a family of rare neurodegenerative pathologies, the common characteristic of these diseases is that their etiology is 


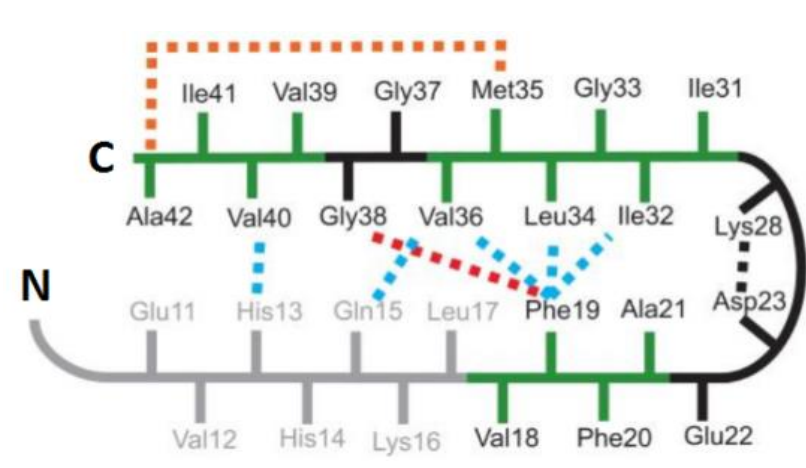

Figure 3. Sequence and structure of the monomeric unit in amyloid fibrils (20).

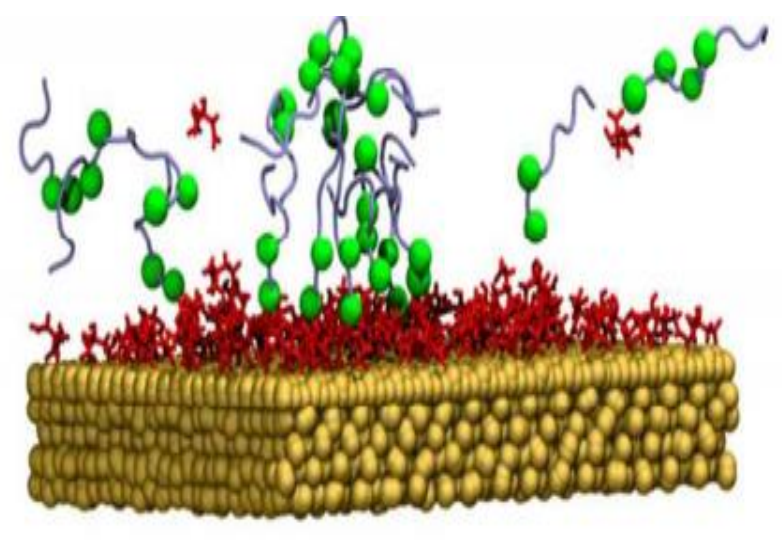

Figure 4. Simulation: Gold surfaces (gold) assembled with specific receptors for $A \beta$ (red) interacting with peptide monomers that bind to the gold surface. C-terminal receptors are depicted as a green sphere to illustrate favored Cterminal binding of the peptide (blue) to the NPAu surface stabilized by iron oxide-rich magnetite cores (16).

group of ENs of the brain of animals and humans. The normal isoform of the prion protein has been identified in mammalian tissues, including sheep, cattle, hamsters, mice and humans, with $80-90 \%$ homology between species and 98\% homology in sheep and cattle prion genes, which would explain the interspecies barrier passage event (21).

\section{CONCLUSIONS}

1. The advances of nanotechnology in health are dedicated to the design of new diagnostic methods, such as AuNP for the early estimation of ENs. For such reason, these NPs are functional to demonstrate the existence of an anomalous structure recognized and exhibited by the same, which is highly sensitive and specific, since the fused receptor acted as a sensor for the detection of prion structures. Therefore, further research studies are required to determine the molecular mechanisms in which the active functioning of the nanostructures is developed, in order to provide different target points in the treatment of various biological particles that would be involved in the progression of such diseases.

2. Since this technique is being used as a possible evaluation in the progression of NDs, it is useful for the possible generation of treatments, which are focused on the reversion of the nervous system symptomatology and the decrease of isolated amyloid plaques in the brain. Some authors propose that the implementation of these molecular biomarkers does not generate side effects in the patient, since theyare not neurotoxic and are biocompatible with the normal metabolism in the organism.

3. At present, there is much knowledge about the clinical characteristics and pathogenesis of the diseases mentioned above, correlated with their alterations at the molecular level. However, with the advent of biotechnology today, it has been possible to design techniques and technologies with NPs that allow the identification of specific mutations and provide a diagnosis in individuals at risk of being a carrier of a neurological disorder. Taking into account the research models concerning AuNP, it is possible to infer that the capabilities that make them representative focus on their magnetism and biofunctionality with different biological molecules, in this case, by binding 
specifically to amyloid peptides and other ligands directed to a C-terminal cysteine domain present in the protein, which is the major component of amyloid plaques used in these studies.

\section{CONFLICT OF INTERESTS}

All authors declare that they have no competing interests.

\section{REFERENCES}

1. Férnandez Cabada T. Caracterización de nanopartículas magnéticas y de oro para posibles aplicaciones biomédicas en diagnóstico y terapia [tesis doctoral]. Madrid: Centro de Tecnología Biomédica, Universidad Politécnica de Madrid; 2015. Available from: http://oa.upm.es/32262/1/TAMARA_FERN ANDEZ_CABADA.pdf [Accessed 21st February 2021].

2. González Rubio G. Synthesis and Assembly of Uniform Plasmonic Gold Nanostructures for Biomedical Applications [tesis doctoral]. Madrid: Facultad de Ciencias Químicas, Universidad Complutense de Madrid; 2018. Available from: https://eprints.ucm.es/id/eprint/ 49068/1/T40161.pdf [Accessed 21st February 2021].

3. Hurtado Ruiz D. Aplicación de la nanotecnología en las enfermedades neurodegenerativas (Application of nanotechnology in neurodegenerative diseases] [final degree project]. Andalucía: Facultad de Ciencias Experimentales, Universidad de Jaén; 2020. Available from: http://tauja.ujaen.es/bitstream/10953.1/12267/1/TFG\%20Quimica \%20\%20Diego\%20Hurtado\%20Ruiz.pdf

[Accessed 21st February 2021].

4. Proteína Priónica Celular (Cell Prion Protein). Universidad de Alcalá. ChemEvol. 2020 Available from: http://www3.uah.es/ chemevol/index.php/2019/12/12/proteinaprionica-celular/ [Accessed 21st February 2021].

5. Toro G, Sierra U, Gómez L. Teoría Prión Enfermedades Priónicas (Prion Theory Prion Diseases). Acta Neurologica Colombiana. 2015. Available from: http:// www.scielo.org.co/scielo.php?script=sci_artt ext\&pid=S0120-87482015000100015 [Accessed 21st February 2021].

6. Pichla M, Bartosz G, Sadowska-Bartosz I. The antiaggregative and antiamyloidogenic properties of nanoparticles: A promising tool for the treatment and diagnostics of neuro- degenerative diseases. Oxid Med Cell Longev. 2020; 2020:3534570. Available from: https://www.hindawi.com/journals/omcl/2 020/3534570/ [Accessed 21st February 2021].

7. Nieto Salazar S. Estudio del aprovechamiento y caracterización de nanopartículas de oro desde la magnetita, extraída de lámina de oro "La Esperanza" (Study of the use and characterization of gold nanoparticles from magnetite, extracted from "La Esperanza") [research work]. Pereira-Risaralda: Facultad de Ingeniería Mecánica, Universidad Tecnológica de Pereira; 2020. doi:10.13140/RG.2.2.35304. 62724

8. Stoica V.A, Laanait N, Dai C, et al. Optical creation of a supercrystal with threedimensional nanoscale periodicity. Nat. Mater. 2019; 18:377-383. doi:10.1038/s41563019-0311-x

9. Lattanzio F, Abu-Rumeileh S, Franceschini A, et al. Prion-specific and surrogate CSF biomarkers in Creutzfeldt-Jakob disease: diagnostic accuracy in relation to molecular subtypes and analysis of neuropathological correlates of p-tau and A $\beta 42$ levels. Acta Neuropathol. 2017;133(4):559-578. Available from: https://pubmed.ncbi.nlm.nih.gov/ 28205010/ [Accessed 8 September 2020].

10. Gómez M, Morales R. Exosomas en la propagación de Enfermedades Neurodegenerativas (Exosomes in the spread of neurodegenerative diseases). Medigraphic.com. 2018. Disponible en: https://www.medigraphic.com/ pdfs/arcneu/ane-2018/ane183a.pdf [Accessed 21st February 2021].

11. Guven Z.P, Jacob Silva P, Luo Z, et al. Synthesis and characterization of Amphiphilic Gold Nanoparticles. Jove. 2019. Available from: https://www.jove.com/v/58872/synthesisand-characterization-of-amphiphilic-goldnanoparticles [Accessed 21st February 2021]. 
12. Alvarez Fuentes J. Aplicación de la nanotecnología al tratamiento de las enfermedades neurológicas (Application of nanotechnology to the treatment of neurological diseases] [final degree project]. Andalucía: Facultad de Farmacia, Universidad de Sevilla; 2020. Available from: https://idus.us.es/bitstream/handle/11441/103142/TFG\%20202 0\%20-\%20M\%c3\%a1rquez\%20Mar\%c3\% adn_\%20Concepci\%c3\%b3n\%20def.pdf?seq uence $=1 \&$ isAllowed $=y$ [Accessed 21st February 2021].

13. Aghaie T, Jazayeri MH, Manian M, Khani L, Erfani M, Rezayi M, et al. Gold nanoparticle and polyethylene glycol in neural regeneration in the treatment of neurodegenerative diseases. J Cell Biochem. 2019;120(3):274955. doi:10.1002/jcb. 27415

14. Gómez M. Usos terapéuticos de nanomateriales y nanopartículas (Therapeutic uses of nanomaterials and nanoparticles). Edu.co. 2019 Avalable from: https://revistas. fucsalud.edu.co/index.php/repertorio/articl e/view/871/914\#to [Accessed 7 March 2021].

15. Martínez Arribas A. Nanosistemas en diagnosis y tratamiento de la enfermedad de Alzheimer (Nanosystems in the diagnosis and treatment of Alzheimer's disease) [final degree project]. Santander: Facultad de Medicina, Universidad de Cantabria; 2019. Available from: https://repositorio.unican.es/ xmlui/bitstream/handle/10902/16647/Mar tinezArribasAlberto.pdf? sequence $=1 \&$ is

Date of receipt of the manuscript: 06/05/2021 Date of acceptance for publication: 09/12/2021

Alejandro ORTIZ, ORCID ID: 0000-0002-3559-6583 Zeyris HERRERA, ORCID ID: 0000-0003-4514-6161 Johanna MOSCOSO, ORCID ID: 0000-0001-9963-5978
Allowed=y [Accessed 21st February 2021].

16. Torsten J, Anika G, Clemens K, Martin LL, Risselada HJ, Abel B. Impact of nanoparticles on amyloid peptide and protein aggregation: a review with a focus on gold nanoparticles. Nanoscale. 2018;10(45):20894-913. doi:10. 1039/c8nr04506b

17. Rai M, Yadav A. Nanobiotechnology in Neurodegenerative Diseases. Cham: Springer. International Publishing; 2019. Available from: https://link.springer.com/book/10.1007\%2 F978-3-030-30930-5 [Accessed 7 Marche 2021].

18. Devitt G, Howard K, Mudher A, Mahajan S. Raman spectroscopy: An emerging tool in neurodegenerative disease research and diagnosis. ACS Chem Neurosci. 2018;9(3):40420. doi:10.1021/acschemneuro.7b00413

19. Zheng X, Wu C, Liu D, Li H, Bitan G, Shea J-E, et al. Mechanism of $\mathrm{C}$-terminal fragments of amyloid $\beta$-protein as $A \beta$ inhibitors: Do $C$ terminal interactions play a key role in their inhibitory activity? $J$ Phys Chem $B$. 2016;120(8):1615-23. doi:10.1021/acs.jpcb. $5 \mathrm{~b} 08177$

20. Ahmed M, Davis J, Aucoin D, et al. Structural conversion of neurotoxic amyloid-beta (142) oligomers to fibrils. Nat Struct Mol Biol. 2010;17(5):561-567. doi:10.1038/nsmb.1799

21. Herrera Z, Ortiz A. Molecular transformation of PrPc to PrpSc in Colombian populations for the pathogenesis of sporadic Creutzfeldt-Jakob disease. UDES. Boletín Informativo, 2020. 